\title{
Effect of drying temperature on qualities of mint
}

\author{
Jiangchangmei $\mathrm{Lu}^{1,2, a}$, Xuemin Wang ${ }^{1, a}$, Chao Zhang ${ }^{2, b}$, Yue $\mathrm{Ma}^{2, \mathrm{c}}$, Xiaoyan
}

$$
\text { Zhao }^{2, d}
$$

\begin{abstract}
1. College of Agriculture, Engineering University of Hebei, Handan, 056001, China; 2.Beijing Vegetable Research Center, Beijing Academy of Agriculture and Forestry Sciences; Beijing Key Laboratory of Fruits and Vegetable Storage and Processing; Key Laboratory of Biology and Genetic Improvement of Horticultural Crops (North China), Ministry of Agriculture; Key Laboratory of Urban

Agriculture (North), Ministry of Agriculture, 9 Shuguanghuayuan Road, Haidian District, Beijing,100097,China
\end{abstract}

a351014355@qq.com, bzhangchao@nercv.org, 'mayue@nercv.org, 'zhaoxiaoyan@nercv.org

\section{Keywords: mint, drying, modeling.}

Abstract: The effect of drying temperature on properties of mint was investigated. A constant rate and a falling period were found during drying process of mint. The maximum chlorophll retention and the minimum value of $\mathrm{a}^{*}$ and $\triangle \mathrm{E}$ was found to be dried at $55^{\circ} \mathrm{C}$. The Modified Page model was the best to describing the drying process with $\mathrm{R}^{2}$ of $0.97522-0.99916$.

\section{Introduction}

Mint (Mentha spicata L.) is a common name for members of the Labiatae ${ }^{[1]}$, which has been used as an aromatic and medicinal plant. Mint can be used as flavoring agents, spices, teas, but also bartending and so on. The drying process of mints has been studied by various models. Ibrahim Doymaz found that the Logarithmic model is the best models to describe thin layer drying of mint

${ }^{[1]}$. Lebert et al. found that the drying air temperature is the main factor in controlling the drying rate

${ }^{[2]}$. Sallam et al. reported that Diffusion approach model is the best models able to describe thin layer solar drying of mint ${ }^{[3]}$. However, hot air drying of mint is not found to our knowledge. Therefore, the effect of drying temperature on qualities of mint was evaluated.

\section{Material and methods}

Material. Fresh mint was harvest in the farm of Beijing Academy of Agriculture and Forestry Sciences, China in August, 2014. Samples were stored in a refrigerator at $4{ }^{\circ} \mathrm{C}$ before use. The initial moisture content of mint was $8.20 \mathrm{~g} / \mathrm{g}$ expressed in dry basis $(\mathrm{db})$.

Drying process. The mint was blanched at $(100 \pm 1){ }^{\circ} \mathrm{C}$ for $1 \mathrm{~min}$. The blanched sample was centrifugally and placed in square tray $(48 \mathrm{~cm} \times 55 \mathrm{~cm})$. The samples $(300 \mathrm{~g})$ were subsequently dried at the temperature of $55,65,75,85,95{ }^{\circ} \mathrm{C}$ respectively. The moisture content was measured according to GB 5009.3-2010 of China.

Mathematical model of drying curves. Drying curves were fitted with seven commonly used thin-layer drying models (Table 1). The moisture ratio of mint during drying experiments was calculated using the following equations:

Moisture Ratio $(M R)=\frac{M_{t}-M_{e}}{M_{0}-M_{e}}$

where $\mathrm{M}_{\mathrm{t}}$ is the moisture content in the course of drying, $\mathrm{M}_{0}$ is the initial moisture content and 
$\mathrm{M}_{\mathrm{e}}$ is the equilibrium moisture content ( $\mathrm{kg}$ water $/ \mathrm{kg}$ dry matter). During the determination of MR, the formula was simplified and the value of $\mathrm{M}_{\mathrm{e}}$ was omitted.

Table 1 Commonly used thin layer drying models

\begin{tabular}{llll}
\hline No. & Model name & Model & References \\
\hline 1 & Lewis & $M R=\exp (-k t)$ & Bruce (1985) \\
2 & Page & $M R=\exp \left(-k t^{n}\right)$ & Page (1949) \\
3 & Modified-Page & $M R=\exp \left(-(k t)^{n}\right)$ & White, Ross, and Ponelert (1981) \\
4 & Wang and Singh & $M R=1+a t+b t^{2}$ & Wang and Singh (1978) \\
5 & Henderson-Pabis & $M R=a \exp (-k t)$ & Henderson and Pabis (1961) \\
6 & Logarithmic & $M R=a \exp (-k t)+c$ & Togrul and Pehlivan (2002) \\
7 & Two-term & $M R=a \exp \left(-k_{0} t\right)+b \exp \left(-k_{1} t\right)$ & Henderson (1974) \\
\hline
\end{tabular}

Determination of water activity. The water activity (aw) was measured at $25{ }^{\circ} \mathrm{C}$ by means of a water activity instrument (Aqua LAB 4TE, Decagon Devices, USA)

Determination of chlorophyll content. The chlorophyll content of mint was measured by following the reported method ${ }^{[3]}$.

Determination of color. The color of mint samples were measured using a Colorimeter (CM-3700d, Konica Minolta, Japan). The $\mathrm{L}^{*}, \mathrm{a}^{*}, \mathrm{~b}^{*}$, and $\Delta \mathrm{E}$ were recorded.

Statistical analysis. The $\mathrm{R}^{2}$ values, the $\chi^{2}$ and $\mathrm{RMSE}$ values were chosen as the criteria for model fit which were calculated using Origin 8.0. The Duncan's test was conducted to analyze the difference between various drying temperatures, using DPS 7.05. A level of $p<0.05$ was considered as statistically significant.

\section{Results and discussion}

Drying modeling. The MR obtained at the drying process was fitted to the seven models listed in Table 1. The results of regression analyses for the seven considered models which were used to evaluate the drying kinetics of mint were presented in Tables $2 . \mathrm{R}^{2}$ values of all the models were higher than 0.95809, and corresponding RMSE, $\chi^{2}$ values were lower than 0.00499 and 0.07061 . All the models described the hot air drying process of mint. Among the models, Modified Page model had the highest $R^{2}$ value $(0.97522-0.99916)$, lowest RMSE value $\left(1.29 \times 10^{-4}-2.95 \times 10^{-3}\right)$ and $\chi^{2}$ value $(0.01138-0.05429)$. Hence, Modified Page model was the best in describing the hot air drying process of mint. Drying curves described by Modified Page were shown in Fig.1. The result was accordance with the hot air drying of aloe vera ${ }^{[4]}$, and hot air drying of ginger slices ${ }^{[5]}$.

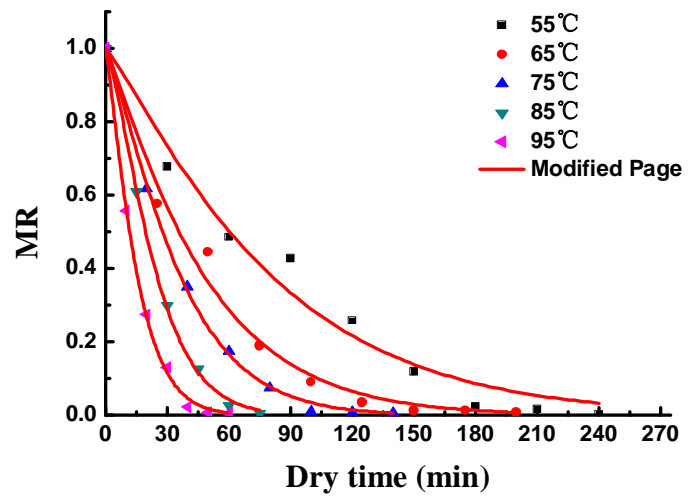

Fig.1.Drying model of Modified Page 
Drying rate. The drying rate versus moisture content of mint was shown in Fig. 2. Two drying periods were found during drying process, namely a constant rate drying period and a falling rate drying period. The result was accordance with Walde et al. ${ }^{[6]}$. At first, DR kept stable with the decreasing of the moisture content (Fig.2). And then, it decreased gradually when the moisture content was below $20 \%(\mathrm{wb})$. DR increased with the increasing of drying temperature in the constant rate drying period, the average values of DR at $55,65,75,85,95^{\circ} \mathrm{C}$ were $0.0093,0.0092$, $0.0126,0.0228,0.0288 \mathrm{~g} / \mathrm{g} \cdot \mathrm{min}$, respectively. Ibrahim Doymaz ${ }^{[7]}$ also found that the drying rate increased with the increasing of drying temperature.

Table 2 Statistical analysis of the models

\begin{tabular}{|c|c|c|c|c|}
\hline Model & $\mathrm{t}\left({ }^{\circ} \mathrm{C}\right)$ & $\mathrm{R}^{2}$ & $\chi^{2}$ & RMSE \\
\hline \multirow{5}{*}{ Lewis } & 55 & 0.97359 & 0.00314 & 0.05605 \\
\hline & 65 & 0.98628 & 0.00163 & 0.04041 \\
\hline & 75 & 0.99195 & 0.00105 & 0.03239 \\
\hline & 85 & 0.98558 & 0.00221 & 0.04701 \\
\hline & 95 & 0.99379 & $8.62 \mathrm{E}-04$ & 0.02936 \\
\hline \multirow{5}{*}{ Page } & 55 & 0.97519 & 0.00295 & 0.05433 \\
\hline & 65 & 0.98709 & 0.00154 & 0.03921 \\
\hline & 75 & 0.99867 & $1.73 \mathrm{E}-04$ & 0.01316 \\
\hline & 85 & 0.99915 & $1.30 \mathrm{E}-04$ & 0.01138 \\
\hline & 95 & 0.99854 & $2.03 \mathrm{E}-04$ & 0.01424 \\
\hline \multirow{5}{*}{ Modified Page } & 55 & 0.97522 & 0.00295 & 0.05429 \\
\hline & 65 & 0.98709 & 0.00154 & 0.0392 \\
\hline & 75 & 0.99867 & $1.73 \mathrm{E}-04$ & 0.01316 \\
\hline & 85 & 0.99916 & $1.29 \mathrm{E}-04$ & 0.01138 \\
\hline & 95 & 0.99854 & $2.03 \mathrm{E}-04$ & 0.01424 \\
\hline \multirow{5}{*}{ Wang \& Singh } & 55 & 0.98265 & 0.00206 & 0.04543 \\
\hline & 65 & 0.97385 & 0.00311 & 0.05579 \\
\hline & 75 & 0.99057 & 0.00123 & 0.03506 \\
\hline & 85 & 0.99928 & $1.10 \mathrm{E}-04$ & 0.01051 \\
\hline & 95 & 0.98821 & 0.00164 & 0.04046 \\
\hline \multirow{5}{*}{ Henderson \& Pabis } & 55 & 0.97007 & 0.00356 & 0.05967 \\
\hline & 65 & 0.98441 & 0.00186 & 0.04308 \\
\hline & 75 & 0.9913 & 0.00113 & 0.03368 \\
\hline & 85 & 0.98322 & 0.00257 & 0.05072 \\
\hline & 95 & 0.99292 & 9.83E-04 & 0.03136 \\
\hline \multirow{5}{*}{ Logarithmic } & 55 & 0.98332 & 0.00198 & 0.04455 \\
\hline & 65 & 0.98584 & 0.00169 & 0.04106 \\
\hline & 75 & 0.996 & $5.21 \mathrm{E}-04$ & 0.02283 \\
\hline & 85 & 0.99445 & $8.51 \mathrm{E}-04$ & 0.02916 \\
\hline & 95 & 0.99663 & $4.68 \mathrm{E}-04$ & 0.02164 \\
\hline \multirow{5}{*}{ Two-term } & 5 & 0.95809 & 0.00499 & 0.07061 \\
\hline & 65 & 0.97818 & 0.0026 & 0.05097 \\
\hline & 75 & 0.98694 & 0.0017 & 0.04125 \\
\hline & 85 & 0.96643 & 0.00514 & 0.07173 \\
\hline & 95 & 0.98819 & 0.00164 & 0.04049 \\
\hline
\end{tabular}

Water activity. The water activity versus drying time was shown in Fig. 2. The initial water 
activity of mint was 0.993 . When aw was higher than 0.95 , it decreased slowly, and then decreased to 0.3 quickly. The higher of the drying temperature was, the faster of aw declined at the second stage. It took 90 minutes to decline aw from 0.968 to 0.298 , at $55^{\circ} \mathrm{C}$. And at $95^{\circ} \mathrm{C}, 30$ minutes was used to decline aw from 0.969 to 0.261 . The drying time of the second stage at $55^{\circ} \mathrm{C}$ was 1 hour longer than that at $95^{\circ} \mathrm{C}$.
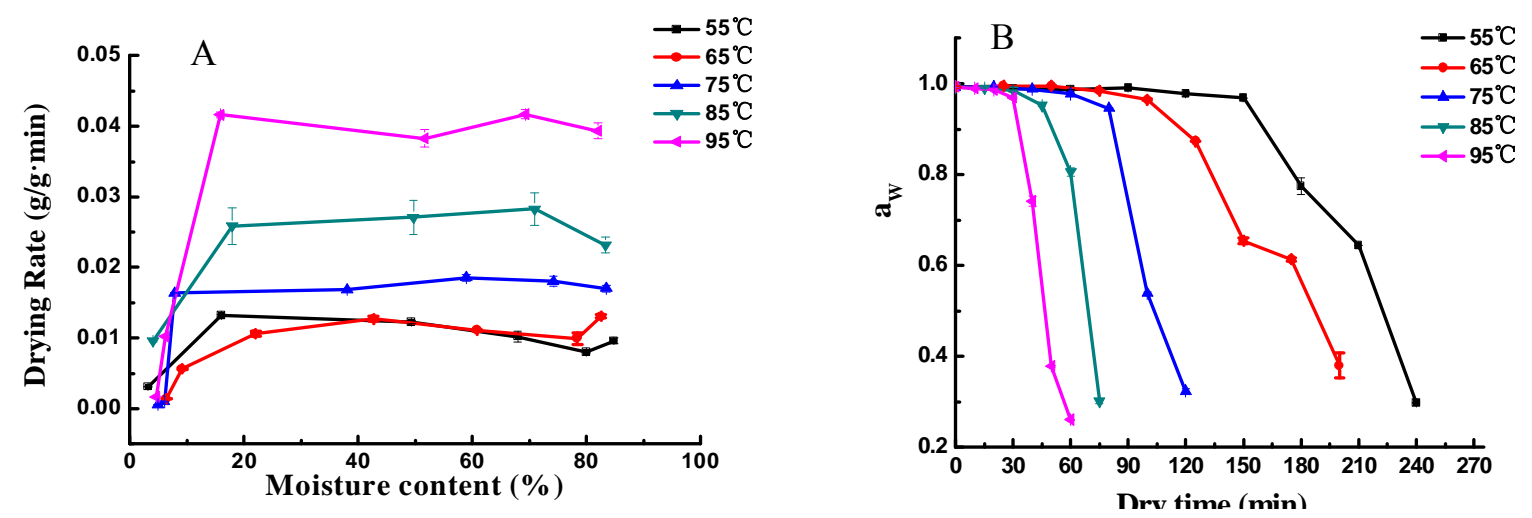

Fig.2. Drying rate versus moisture content (A) and Water activity versus drying time of the mint (B) Chlorophyll content. The Chlorophyll content versus drying time was shown in Fig. 3. The chlorophyll content of fresh mint was $1.76 \mathrm{mg} / \mathrm{g}$ (wet basis). The chlorophyll content was significantly reduced with the increasing of drying time. When drying temperature increased, the degradation rate of chlorophll increased. Dongmei Wang et al. ${ }^{[8]}$ also found that the higher drying temperature would bring a higher degradation rate of chlorophll. When the samples were dried to a moisture content below $6 \%$ (wet basis), chlorophyll contents of samples dried at 55, 65, 75, 85, $95^{\circ} \mathrm{C}$ were $1.25,1.21,1.03,1.08,1.11 \mathrm{mg} / \mathrm{g}$, respectively. Compared with fresh samples, 70.8, 68.7, $58.6,61.3,62.2 \%$ of chlorophll remained after drying at $55-95{ }^{\circ} \mathrm{C}$, respectively. This was because that heating would cause chemical reactions in cells and tissues, resulting in the collapsing of protein-lipid membrane, and then chlorophyll was broken down ${ }^{[8]}$.

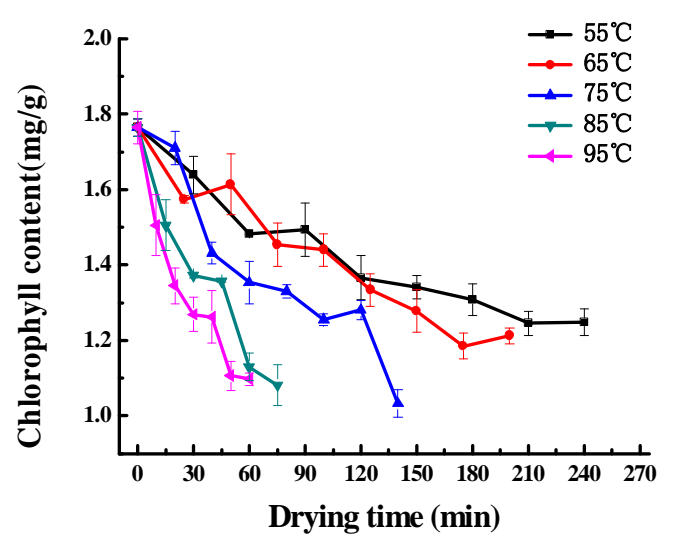

Fig.3.Chlorophyll content versus drying time of mint at different temperatures

Color. Color is one of the most important sensory qualities of products. $L^{*}, a^{*}$ and $b^{*}$ values of fresh mint were $37.3 \pm 0.0497,-9.0 \pm 0.0235,25.1 \pm 0.0581$, respectively (Table 3 ). Drying caused an increase in lightness, a decrease in greenness and yellowness in comparison with the fresh mint samples. $a^{*}$ values were increased with increasing of the drying temperatures. This indicated that samples dried in high temperatures were not as green as fresh samples. This was because that there was a great relationship between $\mathrm{a}^{*}$ value and the color of chlorophll, significant loss of chlorophyll resulting in a decline of a ${ }^{*}$ values $^{[8]}$. $\triangle \mathrm{E}$ reflected the total color difference between dried and fresh samples and a lower value was favorable ${ }^{[9]}$. The minimum value of $\triangle \mathrm{E}$ was $3.96 \pm 0.200$ with 
a drying temperature of $55^{\circ} \mathrm{C}$, and the maximum value of $\triangle \mathrm{E}$ was $17.8 \pm 0.143$ with drying temperatures of $85{ }^{\circ} \mathrm{C}$. Therefore, samples dried at $55^{\circ} \mathrm{C}$ retained the best color in comparison with fresh mint samples.

Table 3 Color of dried mint under different drying temperatures

\begin{tabular}{lllll}
\hline Sample & $\mathrm{L}^{*}$ & $\mathrm{a}^{*}$ & $\mathrm{~b}^{*}$ & $\triangle \mathrm{E}$ \\
\hline Fresh samples & $37.3 \pm 0.0497^{\mathrm{e}}$ & $-9.0 \pm 0.0235^{\mathrm{e}}$ & $25.1 \pm 0.0581^{\mathrm{a}}$ & $/$ \\
$55^{\circ} \mathrm{C}$ & $38.1 \pm 0.0648^{\mathrm{c}}$ & $-7.8 \pm 0.0686^{\mathrm{d}}$ & $21.4 \pm 0.211^{\mathrm{c}}$ & $3.96 \pm 0.200^{\mathrm{d}}$ \\
$65^{\circ} \mathrm{C}$ & $36.2 \pm 0.195^{\mathrm{f}}$ & $-6.5 \pm 0.0335^{\mathrm{c}}$ & $19.1 \pm 0.100^{\mathrm{d}}$ & $6.57 \pm 0.0921^{\mathrm{b}}$ \\
$75^{\circ} \mathrm{C}$ & $37.8 \pm 0.145^{\mathrm{d}}$ & $-6.4 \pm 0.0476^{\mathrm{b}}$ & $22.0 \pm 0.101^{\mathrm{b}}$ & $5.3 \pm 0.342^{\mathrm{c}}$ \\
$85^{\circ} \mathrm{C}$ & $48.8 \pm 0.223^{\mathrm{b}}$ & $-3.9 \pm 0.0305^{\mathrm{a}}$ & $12.5 \pm 0.210^{\mathrm{f}}$ & $17.8 \pm 0.143^{\mathrm{a}}$ \\
$95^{\circ} \mathrm{C}$ & $49.7 \pm 0.362^{\mathrm{a}}$ & $-3.9 \pm 0.133^{\mathrm{a}}$ & $13.6 \pm 0.347^{\mathrm{e}}$ & $17.6 \pm 0.0113^{\mathrm{a}}$ \\
\hline
\end{tabular}

Note: Values expressed are means of 3 replicates \pm standard error of means. Different letters in the same column indicate significant differences $(\mathrm{p}<0.05)$.

\section{Conclusions}

Mathematical modeling showed that Modified Page model was the best in describing the hot air drying process of mint. A constant rate and a falling period were found during drying process. The maximum chlorophll retention and the minimum value of $\mathrm{a}^{*}$ and $\triangle \mathrm{E}$ was found in mint dried at 55 ${ }^{\circ} \mathrm{C} .55^{\circ} \mathrm{C}$ is the most suitable hot air drying temperature for mint.

\section{Acknowledgement}

The authors are grateful to financial support of the earmarked fund for Modern Agro-industry Technology Research System (CARS-26-22 \& CARS-25), Beijing Academy of Agricultural and Forestry Sciences, New Discipline Breeding (KJCX20140204), and Beijing Key Laboratory of Fruits and Vegetable Storage and Processing (Z141105004414037).

\section{References}

[1]Ibrahim Doymaz, Journal of Food Engineering. 74 (2006) 370-375.

[2]Lebert A, Tharrault P, Rocha T, Marty-Audouin C. Food Eng. 17 (1992) 15-28.

[3]Dexiao Li, Yuexia Guo, Haixia Yuan, Min Zhang, Xiaoyan Xi, Fang Mu, Chinese Agricultural Science (In Chinese). 21 (2005) 153-155.

[4]Antonio Vega, Elsa Uribe, Roberto Lemus, Margarita Miranda,LWT. 40 (2007) 1698-1707.

[5]Yuecheng Meng, Lei Wang, Jie Chen, Sheng Fang, Shiyao Li, Food science (In Chinese). 35(2014)100-105.

[6]S.G. Walde, V. Velu , T. Jyothirmayi , R.G. Math, Journal of Food Engineering. 74 (2006) $108-115$.

[7]Ibrahim Doymaz, Journal of Food Engineering. 69 (2005) 161-165.

[8]Dongmei Wang, Yue Ma, Dan Wang, Xiaoyan Zhao, Chao Zhang, Lianzhou Jiang, Scinence and Technology of Food Industry (In Chinese).33(2012)110-113.

[9]Qinqing Chen, Jinfeng Bi, Xinye Wu, Jianyong Yi, Linyan Zhou, Yuhan Zhou, LWT. 64 (2015) 759-766. 